Article

\title{
Influence of Colder Temperature on the Axial and Radial Parenchyma Fraction of Quercus ciliaris C.C.Huang \& Y.T.Chang Wood and Its Relationship with Carbohydrate Reserve (NSC)
}

\author{
Xijin Zhang ${ }^{1}\left(\mathbb{D}\right.$, Dan $\mathrm{Wu}^{1}$, Qingyao $\mathrm{Li}^{1}{ }^{1}$, Faguang Pu ${ }^{2}$, Xingli Xia ${ }^{1} \mathbb{D}$, Mingyang Chang ${ }^{1}$ and Kun Song ${ }^{1,3, * \mathbb{D}}$ \\ 1 Tiantong National Forest Ecosystem Observation and Research Station, Shanghai Key Lab for Urban \\ Ecological Processes and Eco-Restoration, School of Ecological and Environmental Sciences, East China \\ Normal University, Shanghai 200241, China; xjzhang1991@163.com (X.Z.); w9yudan@163.com (D.W.); \\ 51213903038@stu.ecnu.edu.cn (Q.L.); lilyxiachn@outlook.com (X.X.); 51193903025@stu.ecnu.edu.cn (M.C.) \\ 2 Anhui Dabie Mountain Forest Ecosystem National Observation Station, Lu'an 237354, China; \\ faguangpu@gmail.com \\ 3 Institute of Eco-Chongming, Shanghai 202162, China \\ * Correspondence: ksong@des.ecnu.edu.cn
}

check for

updates

Citation: Zhang, X.; Wu, D.; Li, Q.; Pu, F.; Xia, X.; Chang, M.; Song, K. Influence of Colder Temperature on the Axial and Radial Parenchyma Fraction of Quercus ciliaris C.C.Huang \& Y.T.Chang Wood and Its

Relationship with Carbohydrate Reserve (NSC). Forests 2022, 13, 169 https://doi.org/10.3390/f13020169

Academic Editor: Hans Beeckman

Received: 7 December 2021

Accepted: 20 January 2022

Published: 22 January 2022

Publisher's Note: MDPI stays neutral with regard to jurisdictional claims in published maps and institutional affiliations.

Copyright: (C) 2022 by the authors. Licensee MDPI, Basel, Switzerland. This article is an open access article distributed under the terms and conditions of the Creative Commons Attribution (CC BY) license (https:// creativecommons.org/licenses/by/ $4.0 /)$.

\begin{abstract}
Parenchyma in the secondary xylem comprises the main tissue for the storage of nonstructural carbohydrates (NSC) in woody plants. Across species, the amount of parenchyma depends on the general environment of the distribution area and determines to a large extent the NSC storage. However, little information is available on the relationship between parenchyma fractions, NSC storage, and the environmental influences within individual species. This information is crucial to assessing the adaptive capacities of tree populations in the context of increasing the frequency and severity of stress-inducing events. In this study, parenchyma fractions and NSC concentrations of the secondary xylem in trunks of a subtropical evergreen oak (Quercus ciliaris C.C.Huang \& Y.T.Chang) were quantified along an elevational gradient from $700 \mathrm{~m}$ to $1200 \mathrm{~m}$ a.s.l. in eastern China. Air temperatures within the distribution area correlated with altitude were recorded. The results showed that the total parenchyma fractions did not covary with the colder temperatures. However, axial parenchyma fractions were lower with a colder climate, while the fractions of multiseriate rays and total ray parenchyma were higher. Higher concentrations of starch and NSC were significantly associated with larger axial parenchyma fractions. The sugar concentration displayed no significant relationship with parenchyma fractions. These findings suggest that the total parenchyma fractions in secondary xylem do not increase in response to a colder climate, while colder temperatures drive changes in the composition of parenchyma for $Q$. ciliaris.
\end{abstract}

Keywords: cold temperature; non-structural carbohydrate (NSC); soluble sugar; starch; stem

\section{Introduction}

It is well known that the majority of a tree's biomass is contained within the secondary xylem of the stems [1-3]. These woody tissues are generally composed of vessels (and, in some cases, tracheids), fibers, and parenchyma. Among these, parenchyma is linked with multiple plant functions, such as the transport and storage of non-structural carbohydrates (NSC, including starch and soluble sugar) and water, vessel embolism repair, among others [4]. Parenchyma can be further classified as either axial or ray parenchyma [5]. Although the relationship between the properties and functions of woody tissue components, such as vessels and fibers are well studied [6-9], the relationships between the properties and functions of parenchyma are much less well understood [10].

The patterns associated with variations in parenchyma fractions give insight into the functional consequences and ecological significance of low vs. high fractions. For 
example, the total parenchyma fraction in the secondary xylem tends to increase with dryer conditions [5], which may be explained by the functions of parenchyma associated with water storage [11,12], dehydration avoidance [13], and vessel embolism repair [14,15]. Furthermore, although significance was still found in the relationship between mean annual precipitation and ray parenchyma, this was not the case for axial parenchyma [5]. Axial and ray parenchyma are produced by fusiform and ray initials, respectively, of the vascular cambium and run perpendicular to each other $[5,16]$, as well as having different correlations with wood functional traits $[10,17,18]$, suggesting a functional differentiation of axial parenchyma and ray parenchyma. Total parenchyma fractions in the secondary xylem are highly variable across species [5], generally varying between 5 and $10 \%$ in conifers and between 20 and $40 \%$ in angiosperms [19]. These variations in parenchyma fractions can be partially explained by the mean climate of the distribution area. For instance, parenchyma fractions were observed to decrease with colder temperatures across species on a global scale (total parenchyma, ray parenchyma, and axial parenchyma) [5], across China (total parenchyma and ray parenchyma) [20], as well as along an elevational gradient within a mountain range (ray parenchyma) [21]. The trends from these studies support the hypothesis that protection against frost can be an energy-demanding process [5,22,23], which could therefore be an important factor in reducing the parenchyma fraction in woody trees exposed to frost or freezing events.

However, there is not a general trend within species at present. Few studies have investigated the intraspecific responses of parenchyma fractions to environments, specifically [21], even though the intraspecific variability of parenchyma is necessary to assess the adaptive capacities of tree populations in the context of increasing frequency and severity of stress-inducing events. Some studies indicated that colder climates were either associated with an increase, or no observed change, in ray parenchyma fractions [21], or an increase in axial parenchyma fractions [24] within species. There was also a study that indicated ray parenchyma fraction tended to decrease with decreasing forest productivity, which is mainly determined by the thermal regime of the layer of seasonally thawing soil [25]. It has also been reported that fractions of axial parenchyma do not covary with the latitude or elevation within a single species [26]. As mentioned above, there is a likely selection towards a lower parenchyma fraction due to the high energy demands for protecting parenchyma against frost. It is reasonable to hypothesize that either axial or ray parenchyma fractions should decrease for individuals exposed to more freezing winters within a species.

One important function of parenchyma in the secondary xylem is to store NSC, which can significantly improve a plant's ability to adapt to stress [27-30]. Consequently, higher parenchyma fractions may promote higher NSC storage [19,31]. Although the evidence as to whether the amount of NSC is associated with parenchyma fractions is still in the early stages, positive correlations between them have been observed in several recent studies in temperate and subtropical regions at the interspecific level $[10,21,31,32]$. This was not the case in tropical regions, which may result from the more important function of hydraulic capacitance, rather than the carbon storage associated with parenchyma in these areas [31]. However, at the intraspecific level, knowledge of the structural basis of xylem storage is not well established. To our understanding, studies about the relationships between parenchyma fractions and NSC storage are still lacking. Further investigation into the relationships between parenchyma fractions and the NSC storage within species would allow researchers to better understand the adaptive strategies of woody plants.

Quercus ciliaris C.C. Huang \& Y.T. Chang [33,34], is a typical subtropical evergreen oak that reaches both the northern and upper distributional limits of evergreen broadleaved forests in eastern China [35-37]. A decrease in the population density of $Q$. ciliaris approaching the upper distributional limit was mainly driven by a colder climate in the studied area [38]. Therefore, temperature, particularly coldness, is likely the main factor that affects the distribution of $Q$. ciliaris. In this study, the fractions of the secondary xylem parenchyma and NSC concentrations in the trunk of $Q$. ciliaris along an elevational gradient were measured to examine the hypotheses that within the single species, (1) parenchyma 
fractions would decrease towards colder temperatures, and (2) parenchyma fractions would be positively correlated with NSC concentrations.

\section{Materials and Methods}

\subsection{Study Area}

This study was conducted in Tianma National Nature Reserve, located at the junction of Anhui, Henan, and Hubei provinces $\left(115^{\circ} 20^{\prime}-115^{\circ} 50^{\prime} \mathrm{E}, 30^{\circ} 10^{\prime}-31^{\circ} 20^{\prime} \mathrm{N}\right)$, in eastern China. This region is characterized by a subtropical moist monsoon climate. The mean annual temperature (MAT) is $13.8^{\circ} \mathrm{C}$, with an extreme maximum temperature of $38.1^{\circ} \mathrm{C}$ (July) and a minimum of $-23^{\circ} \mathrm{C}$ (January). The mean annual precipitation is $1489 \mathrm{~mm}$, most of which occurs from May to September. This region consists of mixed evergreen and deciduous broad-leaved forests [39] with a transition zone buffering the two forest types $[37,40]$.

In terms of the studied elevational gradient, the MAT varied from $10.7^{\circ} \mathrm{C}$ to $12.8^{\circ} \mathrm{C}$ during the year of sampling, with the coldest month mean temperature (CMMT) varying from $-0.3{ }^{\circ} \mathrm{C}$ to $-2.9^{\circ} \mathrm{C}$ and the warmest month mean temperature (WMMT) varying from $21.3^{\circ} \mathrm{C}$ to $23.8^{\circ} \mathrm{C}$ (Figure 1). The upper elevational limit (ca. $1200 \mathrm{~m}$ a.s.l.) of Q. ciliaris in the study area corresponded to the CMMT of $-2.9^{\circ} \mathrm{C}$, the WMMT of $21.3^{\circ} \mathrm{C}$, and the MAT of $10.7^{\circ} \mathrm{C}$ (Figure 1).
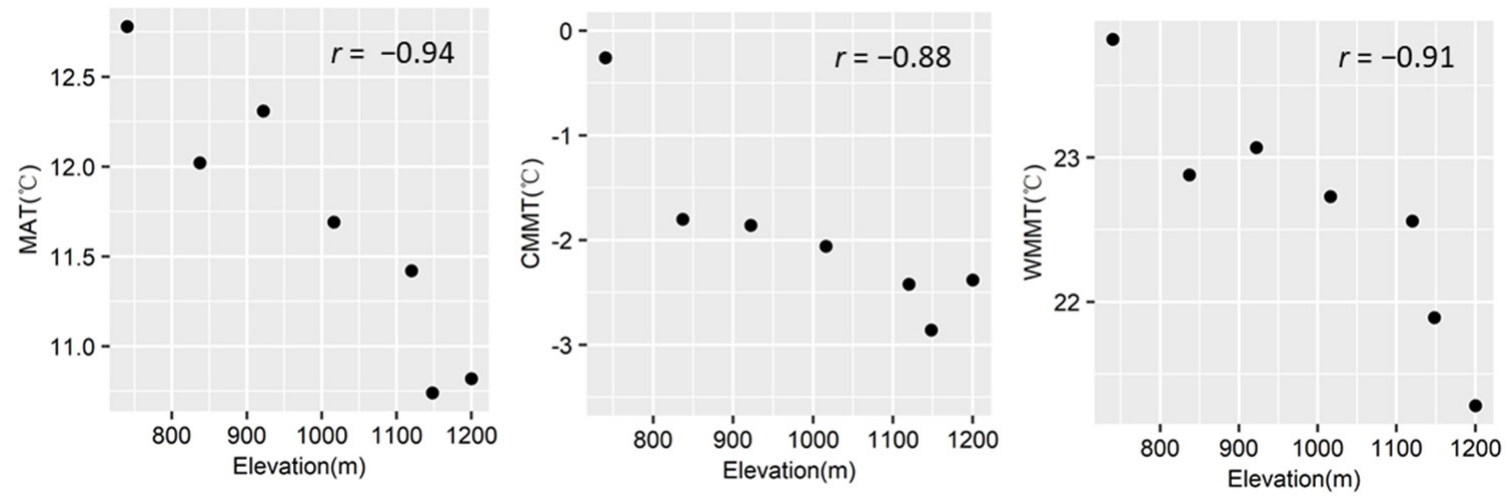

Figure 1. The relationships of temperature variables with elevation. The significant Pearson correlation coefficients were presented $(p<0.05)$. MAT, mean annual temperature; CMMT, the coldest month mean temperature; WMMT, the warmest month mean temperature.

\subsection{Sample Collection and Determination}

Quercus ciliaris, a dominant evergreen broad-leaved canopy tree species, reaches both the northern [36] and upper elevational distributional limits of subtropical evergreen broad-leaved forests $[37,41,42]$ in the studied area. Tree core samples were collected with a $5.15 \mathrm{~mm}$ increment borer (Haglöf, Långsele, Sweden) from three healthy adults at $740 \mathrm{~m}$, $837 \mathrm{~m}, 922 \mathrm{~m}, 1016 \mathrm{~m}, 1120 \mathrm{~m}, 1148 \mathrm{~m}$, and $1200 \mathrm{~m}$ of elevation in October 2018 when no frost nights occurred. According to our monitoring temperature data (see Section 2.3), the mean temperature in October 2017 varied from $10.7^{\circ} \mathrm{C}$ to $12.7^{\circ} \mathrm{C}$ within the studied elevational gradient. Samples were collected from approximately $1 \mathrm{~m}$ above the ground. A total of 21 individuals were sampled. Two cores were collected from each tree, one of which was treated in a microwave oven within $12 \mathrm{~h}$ of sampling in order to denature enzymes [43]. Next, the samples were dried to constant mass at $65^{\circ} \mathrm{C}$. The outer $5 \mathrm{~cm}$ of secondary xylem was used for NSC measurement following an improved phenol-concentrated sulfuric acid method [44].

The second core from each tree was stored in FAA reagent (formalin: glacial acetic acid: ethanol) [45] until it was sectioned for anatomical observations. As the wood of Q. ciliaris is very hard, the cores were boiled for $2 \mathrm{~h}$ to soften the wood for sectioning. Next, transverse sections of entire tree cores approximately $20 \mu \mathrm{m}$ thick were prepared 
using a microtome (WSL core-microtome, WSL, Birmensdorf, Switzerland) as described in Gärtner et al. 2015 [46]. The sections were rehydrated in distilled water and then immersed in a mixture of $0.35 \% w / v$ safranin (in $50 \%$ ethanol) and $0.65 \% w / v$ alcian blue (in distilled water) for $2 \mathrm{~min}$, thoroughly washed with distilled water, and finally they were gradually dehydrated through an ethanol series (55\%,75\%, 95\%, 100\%) before being mounted on a slide in Neo-Mount (Merck Millipore, Darmstadt, Germany) [31] (Figure 2a). One tangential section (Figure $2 b$ ) and one radial section (Figure 2c) were also prepared to help the analysis of the transverse sections [47]. Sequences of digital images were captured using a microscope (Olympus SZ61, Olympus Corporation, Tokyo, Japan), which were then stitched into a composite image of each full tree core using PTGui Pro (version 11.12, New House Internet Services BV, Rotterdam, The Netherlands). The fractions of axial and ray parenchyma were measured in the transverse sections. Since the biseriate or triseriate rays (two or three cells in width) were hardly visible, ray parenchyma was classified into the following two categories: thin rays, including uniseriate and, if any, biseriate or triseriate rays, and multiseriate rays (more than three cells wide).

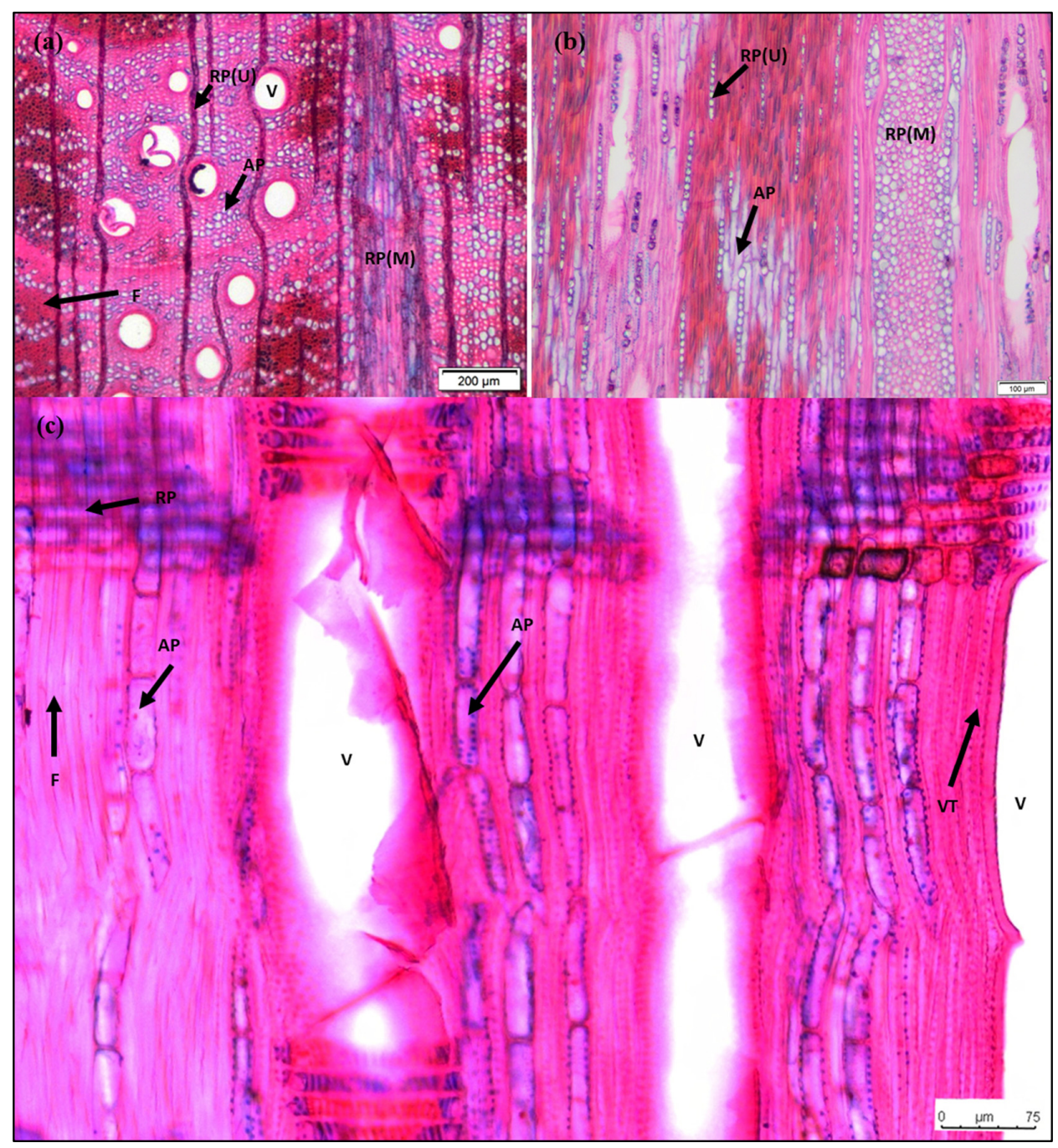

Figure 2. Microscopic sections of a trunk of $Q$. ciliaris tree. (a) Transverse section; (b) Tangential section; (c) Radial section. V, vessels; VT, vasicentric tracheids; F, fibers; AP, axial parenchyma; RP(U), uniseriate ray parenchyma; $\mathrm{RP}(\mathrm{M})$, multiseriate ray parenchyma. The fractions of AP ranged from $4.67 \%$ to $11.67 \%$, the fractions of $R P(R P(U)+R P(M))$ ranged from $13.02 \%$ to $37.84 \%$, and the fractions of total parenchyma (RP $+\mathrm{AP})$ ranged from $20.64 \%$ to $42.99 \%$. 
As the parenchyma fraction of the trunk is known to vary radially [48], the parenchyma fraction for each individual is an averaged fraction calculated over $2 \mathrm{~mm} \times 1 \mathrm{~mm}$ rectangular measurements taken from the outside, middle, and inside of the outer $5 \mathrm{~cm}$ of the composite core image. For a given rectangular measurement area, the fraction of parenchyma was defined as the area of parenchyma divided by the total area. Proportions of axial and ray parenchyma were quantified by manually outlining their areas in different colors in Photoshop software (version 19.1.9, Adobe Systems Inc., San Jose, CA, USA) and then measuring them in ImageJ (version 1.50b, National Institutes of Health, Bethesda, MD, USA). The scatter plots of parenchyma and NSC variables vs. elevation were shown in Figure 3.
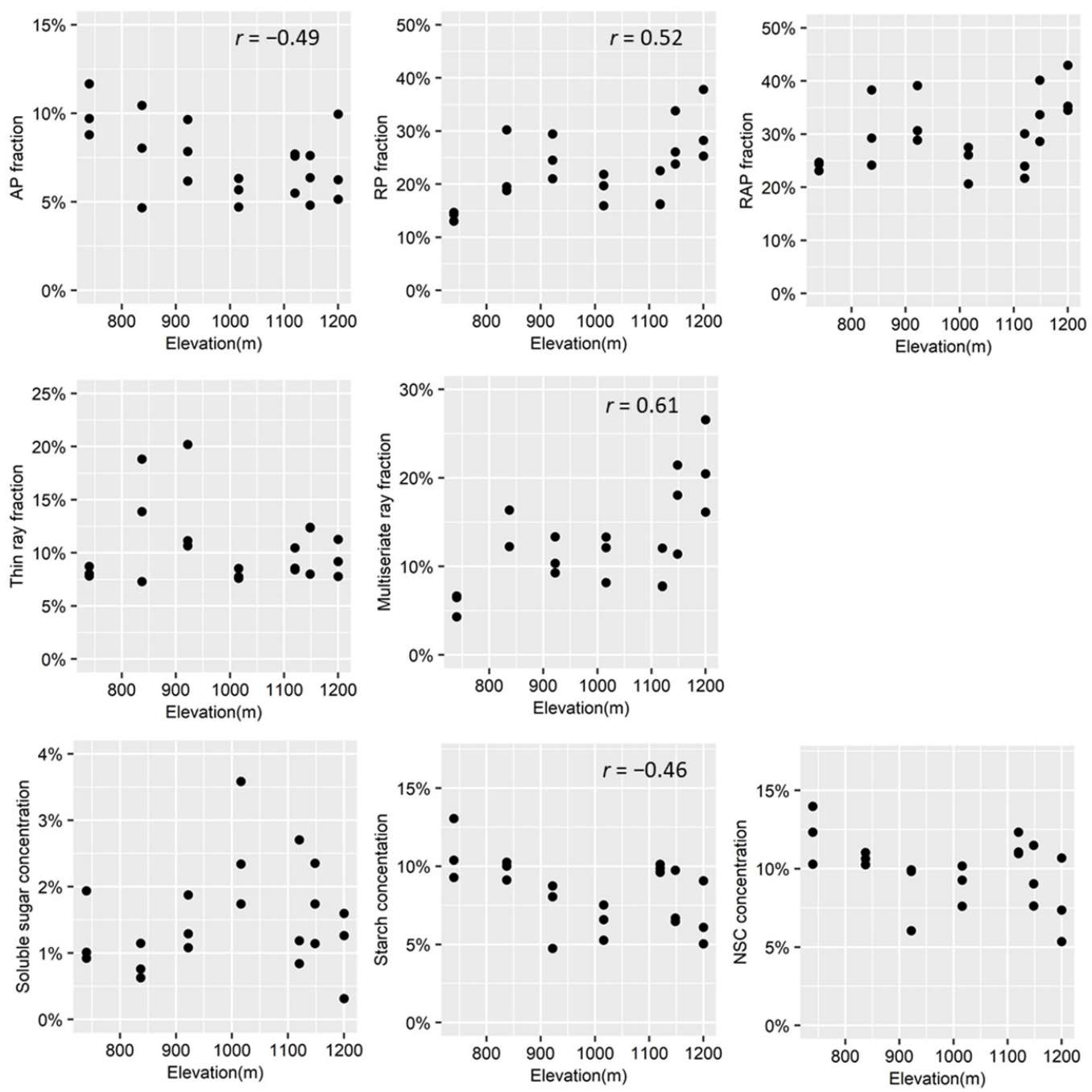

Figure 3. Scatter plots of parenchyma fraction and non-structural carbohydrate concentration (y-axis) vs. Elevation ( $x$-axis). The significant Pearson correlation coefficients were presented $(p<0.05)$ AP, axial parenchyma; $\mathrm{RP}$, ray parenchyma (multiseriate rays + thin rays); RAP, AP + RP; NSC, total non-structural carbohydrate (soluble sugar + starch).

To visualize the distribution of starch within the samples, transverse sections were stained with Lugol's solution for $2 \mathrm{~min}$ and then thoroughly washed in distilled water for immediate observation with a microscope (Olympus SZ61, Olympus Corporation, Tokyo, Japan) (Figure 4). 


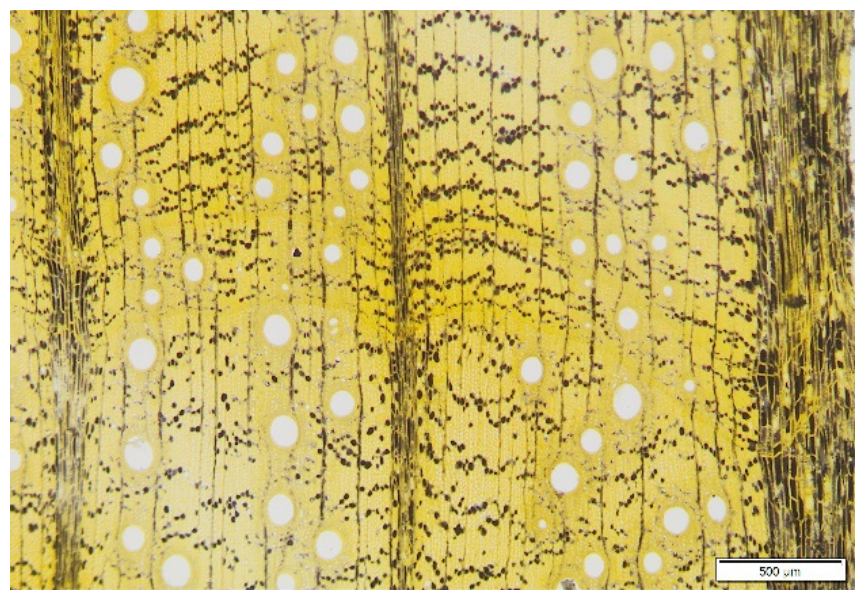

Figure 4. Transverse section of a Q. ciliaris trunk stained with Lugol's solution showing the spatial distribution of starch in wood (stained in black).

The detailed procedure for measuring NSC concentrations is described as follows: because NSC concentration of the trunk is known to vary radially [49], all the outer $5 \mathrm{~cm}$ of the dried tree cores were crushed into a fine powder. The soluble sugars were extracted by weighing about $40 \mathrm{mg}$ of powder into a centrifuge tube and recording the weight, adding $10 \mathrm{~mL}$ of $80 \%$ ethanol into tubes and incubating the closed tubes in a water bath for $60 \mathrm{~min}$ at $80{ }^{\circ} \mathrm{C}$ followed by centrifuging at $4000 \mathrm{r} / \mathrm{min}(2200 \times \mathrm{g})$ for $15 \mathrm{~min}$. The supernatant was transferred to $100 \mathrm{~mL}$ volumetric flasks. $5 \mathrm{~mL}$ of $80 \%$ ethanol was then added to the tubes. The processes of water bath, centrifuging, and supernatant collection were then repeated. The total volume of the combined supernatant was adjusted to $100 \mathrm{~mL}$ for later measurement.

Starch remaining in the undissolved pellet after drying the residuals in the tubes was hydrolyzed in a boiling $3 \% \mathrm{HCl}$ solution for $3 \mathrm{~h}$. Moreover, after filtering the solution into a new batch of $100 \mathrm{~mL}$ volumetric flasks, the total volume of the solution was adjusted to $100 \mathrm{~mL}$ to be measured later.

In a glass tube, $1 \mathrm{~mL}$ of the extracting solution and $1 \mathrm{~mL} 28 \%$ phenol solution $(84 \mathrm{~g}$ phenol adding $80 \%$ ethanol to $300 \mathrm{~g}$ ) were added. Immediately afterwards, $5 \mathrm{~mL}$ concentrated sulfuric acid was added. The tube was shaken for $1 \mathrm{~min}$ and rested for at least $15 \mathrm{~min}$ before absorbance was measured at $490 \mathrm{~nm}$ (UV-9600). The standard solution was sucrose. The sum of soluble sugar and starch concentration was referred to as "total non-structural carbohydrates" (NSC).

\subsection{Temperature Measurement}

The air temperature of each sampling site was recorded hourly for one year (October 2017-September 2018) using a НОВO Pro data logger (U23-001 Pro v2, Onset Computer Corporation, Bourne, MA) mounted approximately $1.5 \mathrm{~m}$ above the ground. As preliminary observations on the population density of $Q$. ciliaris in the study area showed that a decrease in population density approaching the elevational distributional limit was mainly driven by colder climate [38], as well as the upper distributional limits of evergreen broadleaved forests in East Asia correspond with mean temperature of the coldest month [50], the temperature time series data were summarized to calculate the coldest month mean temperature (CMMT) as the temperature index (Figure 1).

\subsection{Data Analysis}

Since the residuals of linear mixed models did not comply with normal distribution, we employed generalized linear mixed models utilizing a beta error structure and a logit link function to test the effects of temperature on the fractions of parenchyma using temperature as a fixed effect and elevation as a random effect. Elevation was included as a random 
effect in each linear mixed model since individuals occurring at the same elevation may be more similar and could therefore violate the assumption of independence. Ordinary linear regression was used to test the influence of parenchyma fraction on NSC. To explore the multiple correlation patterns in parenchyma and NSC, we also conducted a principal component analysis (PCA). All statistical analyses were implemented in R software (version 4.0.2) [51]. Generalized linear mixed models were written using the glmmTMB function in the glmmTMB package (version 1.1.2.3) [52]. The simulate Residuals function in the DHARMa package [53] was used for residual diagnostics of the generalized linear mixed models. Ordinary linear regression was performed with the $1 \mathrm{~m}$ function in the base package [51]. PCA was performed using the rda function in the vegan package (version 2.5.6) [54].

\section{Results}

\subsection{Variations in Parenchyma Fractions along a Temperature Gradient}

The axial parenchyma fractions decreased significantly with a colder CMMT (Table 1). Meanwhile, the fractions of multiseriate ray parenchyma and total ray parenchyma increased significantly with a colder CMMT (Table 1). The fractions of thin ray parenchyma and total parenchyma displayed a non-significant linear relationship with CMMT (Table 1).

Table 1. Generalized linear mixed models test the effects of the coldest month mean temperature (CMMT) on the fraction of axial parenchyma, ray parenchyma, multiseriate ray, thin ray, and total parenchyma.

\begin{tabular}{cccccc}
\hline Response Variable & Parameters & Estimate & SE & $z$ & $p$ \\
\hline \multirow{2}{*}{ Axial parenchyma } & Intercept & -2.14 & 0.13 & -16.50 & $<0.01$ \\
& CMMT & 0.20 & 0.06 & 3.18 & $<0.01$ \\
Ray parenchyma & Intercept & -1.83 & 0.24 & -7.80 & $<0.01$ \\
& CMMT & -0.30 & 0.11 & -2.69 & $<0.01$ \\
Total parenchyma & Intercept & -1.17 & 0.21 & -5.63 & $<0.01$ \\
& CMMT & -0.16 & 0.10 & -1.63 & 0.10 \\
Multiseriate ray & Intercept & -2.82 & 0.33 & -8.52 & $<0.01$ \\
& CMMT & -0.43 & 0.15 & -2.79 & $<0.01$ \\
Thin ray & Intercept & -2.27 & 0.21 & -10.86 & $<0.01$ \\
& CMMT & -0.06 & 0.10 & -0.59 & 0.56 \\
\hline
\end{tabular}

\subsection{Relationships between Parenchyma Fractions and Carbohydrate Storage}

The results of the linear models indicated that NSC concentrations were not significantly associated with the total parenchyma fraction. However, a significantly positive correlation was identified between NSC and the axial parenchyma fraction, along with a significantly negative linear relationship between the fraction of ray parenchyma or multiseriate ray and NSC concentration (Figure 5). Neither the fraction of any kind of ray parenchyma nor the total parenchyma exhibited linear associations with starch concentration. However, starch concentration was positively associated with the axial parenchyma fraction (Figure 5). No significant linear relationships were identified for soluble sugar concentration and any kind of parenchyma (Figure 5).

The results from the PCA show that the first and second axes accounted for $72.20 \%$ of the total variation (Figure 6). The PCA confirmed that fractions of axial parenchyma, starch concentration, and NSC concentration displayed positive correlations with each other. The PCA showed that NSC was also negatively correlated with multiseriate rays. Fractions of total parenchyma were positively associated with ray parenchyma and its two components (multiseriate and thin ray). However, no correlation was identified between the fraction of ray parenchyma and the fraction of axial parenchyma. 

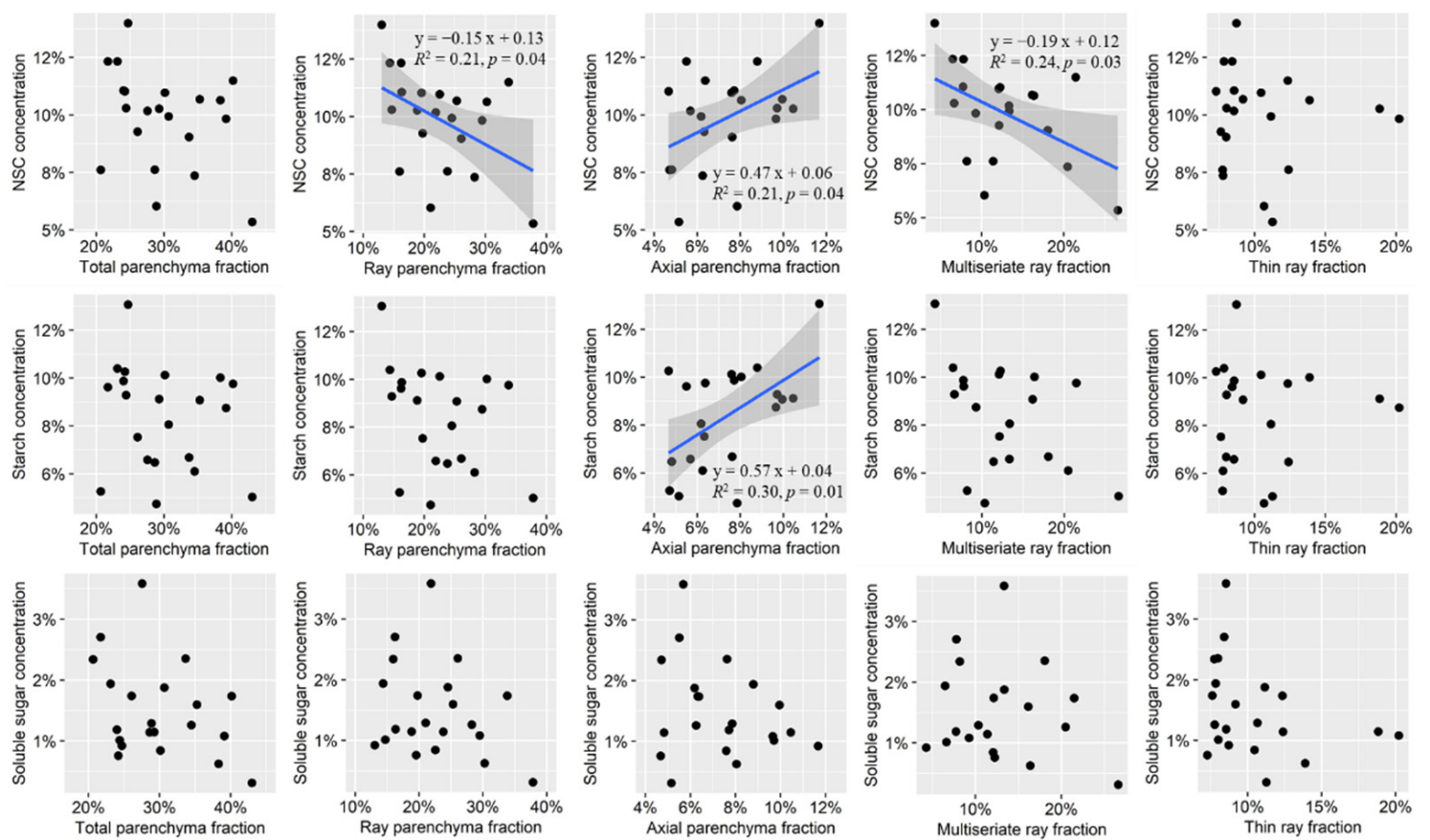

Figure 5. Linear models test the effects of fraction of axial parenchyma, ray parenchyma, multiseriate ray parenchyma, thin ray parenchyma, and total parenchyma on the concentration of soluble sugar, starch, and total non-structural carbohydrates (NSC). The blue lines indicate that the relationships were significant $(p<0.05)$.

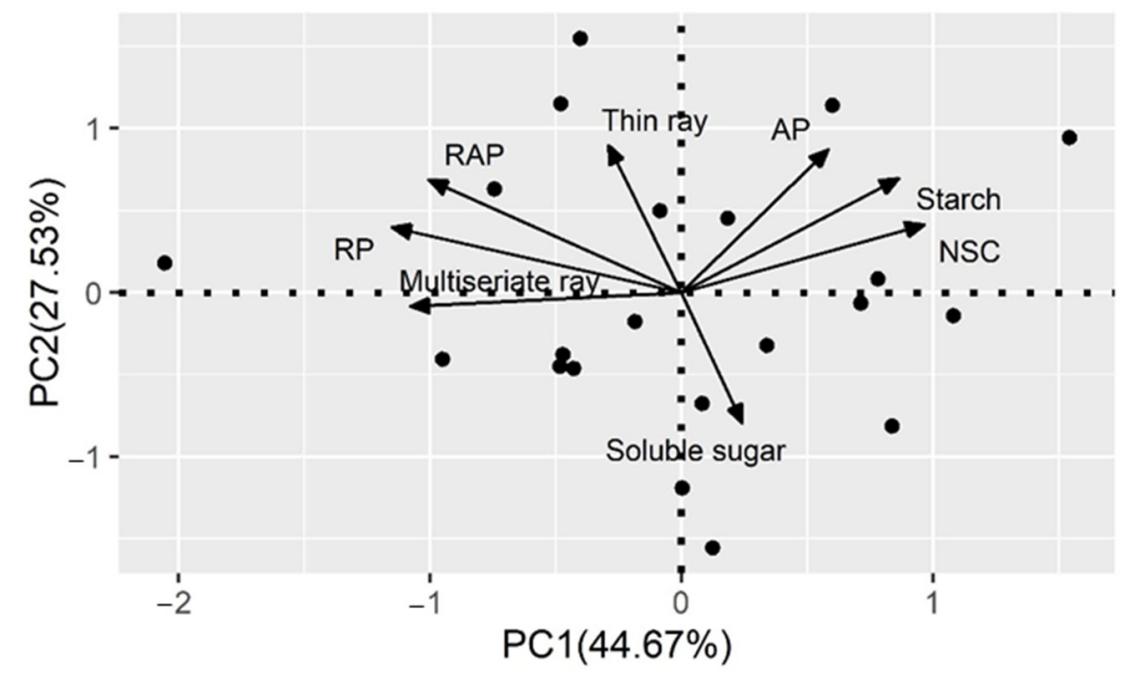

Figure 6. Principal component analysis for the fraction of parenchyma (AP, axial parenchyma; RP, ray parenchyma (including multiseriate and thin ray parenchyma); $\mathrm{RAP}=\mathrm{RP}+\mathrm{AP}$ ) and non-structural carbohydrate (NSC $=$ Soluble sugar + starch) concentration of 21 individuals. One point represents one individual.

\section{Discussion}

Currently, scientific literature investigating the variations in parenchyma fractions along environmental gradients at the intraspecific level is lacking, although several studies have conducted analyses across species $[5,20,21]$. In this study, a species of evergreen oak (Q. ciliaris) found in the northern subtropics of China was employed to investigate the variations in the parenchyma fractions along a temperature gradient. Our main findings show no changes in total parenchyma fractions with a colder climate, suggesting that the xylem storage capacity may not increase with the increasingly stressful conditions 
within the single species. A possible explanation for this may be that maintaining more living cells, as well as protecting them from frost damage, can be an energy-demanding process $[5,22,23]$. However, the trends of axial and ray parenchyma diverged with a colder climate, suggesting a functional differentiation of axial parenchyma and ray parenchyma. There is much indirect or direct evidence to support the suggestion in previous studies. Axial and ray parenchyma diverged, with climate having little influence over the amount of ray parenchyma, unlike axial parenchyma with regards to general trends over more than a thousand species [5]. Axial and ray parenchyma are produced by the fusiform and ray initials of the vascular cambium, respectively, and run perpendicular to each other $[5,16]$. The axially oriented axial parenchyma tends to perform the hydraulic function, since positive correlations between hydraulic efficiency and axial parenchyma fraction have been repeatedly found $[17,18]$. Ray parenchyma is oriented radially and thus can perform the functions of radial transfer [55] and mechanical support [4,17]. Unlike the axial parenchyma, the ray parenchyma fraction is negatively related to hydraulic efficiency $[10,17,18]$.

Axial parenchyma fractions decreased with colder temperatures for $Q$. ciliaris adult trees (Table 1), which is consistent with the decreasing trend in axial parenchyma across angiosperm species on a global scale [5], and a tendency toward less abundant axial parenchyma at higher latitudes within the Ilex genus [56], as well as a tendency toward less abundant axial parenchyma in trees at higher latitudes in Brazil [57]. However, fractions of axial parenchyma for Buddleja cordata Kunth did not covary with latitude or elevation in Mexico [26], but increased with lower temperatures for Paubrasilia echinata (Lam.) Gagnon, H.C.Lima \& G.P.Lewis in Brazil [24]. Therefore, while most studies confirmed that lower fractions of axial parenchyma would likely be observed at sites with low temperatures or high latitudes across species, there are not enough studies to establish the general trends within species. To our knowledge, the formation of air embolisms in vessels due to winter freezing is critical for the distribution of evergreen broad-leaved trees [58]. While all the axial parenchyma of $Q$. ciliaris were apotracheal parenchyma (Figure 2), each vessel of Quercus is sheathed by many layers of vasicentric tracheids, which serve as subsidiary conductive cells [16]. The abundant vasicentric tracheids were intermixed with the parenchyma (Figure 2), forming the connective tissue between vessels [59]. Quercus that evolved in climates with drier, hotter summers or colder winters had higher numbers of vasicentric tracheids than those from mesic climates, supporting the hypotheses that vasicentric tracheids are critical for water transport during drought [60]. Therefore, compared to a high total apotracheal parenchyma fraction, the abundant vasicentric tracheids intermixed with a small amount of parenchyma of $Q$. ciliaris (Figure 2) may be more critical for stabilizing hydraulic capacity during freezing winters. Consequently, the less axial parenchyma fraction may not have much influence on hydraulic capacity during winter. Additionally, smaller vessels were linked with higher resistance to freezing-induced cavitation [6]. In our study, the decreasing fraction of axial parenchyma may also result from the decreased diameter of vessels with increasing elevation $[61,62]$, since vessel diameter can be positively associated with axial parenchyma fraction, whether across species [24,63] or within species [24]. These trends in vessel properties of $Q$. ciliaris with temperature are beyond the scope of this paper and warrant further investigation.

Although ray parenchyma fractions in woody angiosperm species have been shown to decrease with colder temperatures or towards higher latitudes across species [20,21], our study showed an increasing trend in the fraction of ray parenchyma with colder temperatures within the single species (Table 1). A previous study with a focus on Juniperus thurifera (an evergreen conifer) indicated that the mean temperature in the previous October and in the current August was negatively associated with the fraction of ray parenchyma after controlling for ring-width [64]. There was also a similar result for ray parenchyma fraction in evergreen conifers, where the fraction tended to increase with colder temperatures, while the ray parenchyma fraction in an evergreen oak (Quercus chrysolepis) did not significantly vary with temperature within the species [21]. In our study, the increasing trend of ray parenchyma fraction was mainly driven by the multiseriate ray fraction (Table 1). It was 
hypothesized that wide and tall rays were able to adapt better to seasonal changes in water storage than narrow and short rays [16]. Consequently, we speculated that the increasing multiseriate ray parenchyma fraction towards more freezing winter climates may help repair vessel embolism by storing more water or radially transferring water from phloem to xylem.

In our study, total NSC concentration was positively correlated with fractions of axial parenchyma in trunks of $Q$. ciliaris, which was largely due to the positive correlation between starch concentration and axial parenchyma fraction (Figures 5 and 6). The axial parenchyma fraction may be a proxy for the concentration of NSC (especially for starch) for $Q$. ciliaris. Positive correlations between starch or total NSC concentration and axial parenchyma fraction were also observed in previous inter-species studies with a much higher $R^{2}(\geq 0.5)[10,65]$ than in our study $(0.21$ or 0.30 in our study). The low sample size in the study may partly explain the lower $R^{2}$. While NSC concentration showed a weak positive correlation with the ray parenchyma fraction across species for three oaks [21], a significantly negative correlation was observed in our study for a single species. This negative trend was mainly caused by the opposing trends of axial parenchyma and ray parenchyma with temperature.

While most evidence to date has demonstrated a positive correlation between the parenchyma fraction and the concentration of starch or NSC, little evidence has been collected for the correlation between the parenchyma fraction and the soluble sugar concentration. While soluble sugar reaches its highest level in the dormant season [66], all previous studies have been sampled during the growing season. Therefore, a lack of observed correlation may be due to inappropriate sampling design, and tests occurring in the dormant season are therefore recommended. There is a known dynamic of NSC within the dormant season $[67,68]$. Starch is being mobilized long before bud burst $[68,69]$. The timing of sampling for starch/sugar analysis is crucial, and the choice of the right moment should be underpinned by detailed data on the periodicity of NSC dynamics. Therefore, for further study, it is better to carry out sampling monthly with large sample sizes in different phenological periods to verify the detailed dynamics of the movement and concentration of NSC during the whole year. Combined with visualizing starch grains in parenchyma at different phenological stages, the roles of different parenchyma in carbon storage can be more clearly distinguished.

In addition, previous studies have also shown that tree heights are associated with wood anatomy and hydraulic functions. For example, taller trees have predictably wider vessels [70]. Additionally, wood anatomy and hydraulic functions changed when measured at different points from the stem tip towards the base [71]. That means standardizing measurements by distance between the stem tip and tree height should improve comparability between different individuals [71]. Even though all the trees sampled in the current study were mature individuals, the effects of tree size were not taken into account. In further studies, standardizing measurements by distance between the stem tip and tree height is recommended to enhance comparability.

\section{Conclusions}

In this study, we employed a species of evergreen oak to investigate the variations in parenchyma fraction along a temperature gradient, along with the relationships between the parenchyma fraction and the NSC concentration at the end of a growing season in a northern subtropical region. The fraction of total parenchyma did not increase with colder temperatures. However, the axial parenchyma and ray parenchyma fractions changed in different trends with proximity to the elevational distribution limit of Q. ciliaris. Axial parenchyma fractions were lower for individuals in colder climates, while the opposite trend was true for ray parenchyma. The increasing trend of ray parenchyma fraction mainly resulted from the variations in the multiseriate ray fractions. As part of the structural basis of xylem storage, the axial parenchyma fraction was a proxy for the concentration of NSC, especially for starch concentration. While many studies investigating the links between 
the parenchyma fractions and their functions have been performed across species, such investigations have been rare within species. Therefore, to improve our understanding of the physiological significance of variations in parenchyma fraction, similar studies across and within species are needed.

Author Contributions: Conceptualization, X.Z. and K.S.; Formal analysis, X.Z., D.W., Q.L., X.X. and M.C.; Funding acquisition, K.S.; Investigation, X.Z., Q.L., F.P., X.X. and M.C.; Methodology, K.S.; Project administration, X.Z. and K.S.; Supervision, K.S.; Writing-Original draft, D.W.; WritingReview \& editing, X.Z., F.P. and K.S. All authors have read and agreed to the published version of the manuscript.

Funding: This research was funded by the National Natural Science Foundation of China [31500355, 31670438].

Institutional Review Board Statement: Not applicable.

Informed Consent Statement: Not applicable.

Data Availability Statement: The data presented in this study are available on request from the corresponding author.

Acknowledgments: The authors thank Aicui Tu, Zhaofu Chu, and Zuhua Song for their invaluable help with field sampling work in the Dabie mountains. We would like to thank Shannon Elliot at Michigan State University for his assistance with English language and grammatical editing.

Conflicts of Interest: The authors declare no conflict of interest.

\section{References}

1. Puglielli, G.; Laanisto, L.; Poorter, H.; Niinemets, Ü. Global patterns of biomass allocation in woody species with different tolerances of shade and drought: Evidence for multiple strategies. New Phytol. 2021, 229, 308-322. [CrossRef] [PubMed]

2. Reich, P.B.; Luo, Y.; Bradford, J.B.; Poorter, H.; Perry, C.H.; Oleksyn, J. Temperature drives global patterns in forest biomass distribution in leaves, stems, and roots. Proc. Natl. Acad. Sci. USA 2014, 111, 13721-13726. [CrossRef] [PubMed]

3. Zhang, H.; Wang, K.; Xu, X.; Song, T.; Xu, Y.; Zeng, F. Biogeographical patterns of biomass allocation in leaves, stems and roots in China's forests. Sci. Rep. UK 2015, 5, 15997. [CrossRef]

4. Słupianek, A.; Dolzblasz, A.; Sokołowska, K. Xylem Parenchyma-Role and Relevance in Wood Functioning in Trees. Plants 2021, 10, 1247. [CrossRef]

5. Morris, H.; Plavcova, L.; Cvecko, P.; Fichtler, E.; Gillingham, M.A.; Martinez-Cabrera, H.I.; McGlinn, D.J.; Wheeler, E.; Zheng, J.; Zieminska, K.; et al. A global analysis of parenchyma tissue fractions in secondary xylem of seed plants. New Phytol. 2016, 209, 1553-1565. [CrossRef]

6. Hacke, U.G.; Sperry, J.S. Functional and ecological xylem anatomy. Perspect. Plant Ecol. Evol. Syst. 2001, 4, 97-115. [CrossRef]

7. Hietz, P.; Rosner, S.; Hietz-Seifert, U.; Wright, S.J. Wood traits related to size and life history of trees in a Panamanian rainforest. New Phytol. 2017, 213, 170-180. [CrossRef]

8. Janssen, T.A.J.; Hölttä, T.; Fleischer, K.; Naudts, K.; Dolman, H. Wood allocation trade-offs between fiber wall, fiber lumen, and axial parenchyma drive drought resistance in neotropical trees. Plant Cell Environ. 2020, 43, 965-980. [CrossRef] [PubMed]

9. $\quad$ Preston, K.A.; Cornwell, W.K.; Denoyer, J.L. Wood density and vessel traits as distinct correlates of ecological strategy in 51 California coast range angiosperms. New Phytol. 2006, 170, 807-818. [CrossRef]

10. Kawai, K.; Minagi, K.; Nakamura, T.; Saiki, S.T.; Yazaki, K.; Ishida, A. Parenchyma underlies the interspecific variation of xylem hydraulics and carbon storage across 15 woody species on a subtropical island in Japan. Tree Physiol. 2021, 00, 1-14. [CrossRef]

11. Borchert, R.; Pockman, W.T. Water storage capacitance and xylem tension in isolated branches of temperate and tropical trees. Tree Physiol. 2005, 25, 457-466. [CrossRef]

12. Carlquist, S. Living cells in wood. 1. Absence, scarcity and histology of axial parenchyma as keys to function. Bot. J. Linn. Soc. 2015, 177, 291-321. [CrossRef]

13. Pratt, R.B.; Tobin, M.F.; Jacobsen, A.L.; Traugh, C.A.; De Guzman, M.E.; Hayes, C.C.; Toschi, H.S.; MacKinnon, E.D.; Percolla, M.I.; Clem, M.E.; et al. Starch storage capacity of sapwood is related to dehydration avoidance during drought. Am. J. Bot. 2021, 108, 91-101. [CrossRef]

14. Salleo, S.; Lo Gullo, M.; Trifilo, P.; Nardini, A. New evidence for a role of vessel-associated cells and phloem in the rapid xylem refilling of cavitated stems of Laurus nobilis L. Plant. Cell Environ. 2004, 27, 1065-1076. [CrossRef]

15. Trifilò, P.; Kiorapostolou, N.; Petruzzellis, F.; Vitti, S.; Petit, G.; Lo Gullo, M.A.; Nardini, A.; Casolo, V. Hydraulic recovery from xylem embolism in excised branches of twelve woody species: Relationships with parenchyma cells and non-structural carbohydrates. Plant. Physiol. Bioch. 2019, 139, 513-520. [CrossRef] [PubMed] 
16. Carlquist, S. Comparative Wood Anatomy: Systematic, Ecological, and Evolutionary Aspects of Dicotyledon Wood; Springer: Berlin/Heidelberg, Germany, 2001.

17. Zheng, J.; Martínez-Cabrera, H.I. Wood anatomical correlates with theoretical conductivity and wood density across China: Evolutionary evidence of the functional differentiation of axial and radial parenchyma. Ann. Bot. 2013, 112, 927-935. [CrossRef]

18. Aritsara, A.N.A.; Razakandraibe, V.M.; Ramananantoandro, T.; Gleason, S.M.; Cao, K.F. Increasing axial parenchyma fraction in the Malagasy Magnoliids facilitated the co-optimisation of hydraulic efficiency and safety. New Phytol. 2021, 229, 1467-1480. [CrossRef]

19. Plavcová, L.; Jansen, S. The Role of Xylem Parenchyma in the Storage and Utilization of Nonstructural Carbohydrates; Springer International Publishing: Cham, Switzerland, 2015; pp. 209-234.

20. Zheng, J.; Zhao, X.; Morris, H.; Jansen, S. Phylogeny Best Explains Latitudinal Patterns of Xylem Tissue Fractions for Woody Angiosperm Species Across China. Front. Plant Sci. 2019, 10, 556. [CrossRef]

21. Godfrey, J.M.; Riggio, J.; Orozco, J.; Guzman-Delgado, P.; Chin, A.; Zwieniecki, M.A. Ray fractions and carbohydrate dynamics of tree species along a $2750 \mathrm{~m}$ elevation gradient indicate climate response, not spatial storage limitation. New Phytol. 2020, 225, 2314-2330. [CrossRef] [PubMed]

22. Sperling, O.; Earles, J.M.; Secchi, F.; Godfrey, J.; Zwieniecki, M.A. Frost Induces Respiration and Accelerates Carbon Depletion in Trees. PLoS ONE 2015, 10, e144124. [CrossRef]

23. Wisniewski, M.; Davis, G. Immunogold localization of pectins and glycoproteins in tissues of peach with reference to deep supercooling. Trees Struct. Funct. 1995, 9, 253-260.

24. Macedo, T.M.; Lima, H.C.D.; de Souza, N.D.; Gonçalves, A.C.; Costa, C.G.; Barros, C.F. Intraspecific variation of Paubrasilia echinata (Fabaceae) wood along a latitudinal gradient in Brazil. Flora 2019, 258, 151437. [CrossRef]

25. Fonti, P.; Tabakova, M.A.; Kirdyanov, A.V.; Bryukhanova, M.V.; von Arx, G. Variability of ray anatomy of Larix gmelinii along a forest productivity gradient in Siberia. Trees 2015, 29, 1165-1175. [CrossRef]

26. Aguilar-Rodríguez, S.; Terrazas, T.; López-Mata, L. Anatomical wood variation of Buddleja cordata (Buddlejaceae) along its natural range in Mexico. Trees 2006, 20, 253-261. [CrossRef]

27. Chapin, I.F.S.; Schulze, E.D.; Mooney, H.A. The ecology and economics of storage in plants. Annu. Rev. Ecol. Syst. 1990, 21, 423-447. [CrossRef]

28. Morin, X.; Améglio, T.; Ahas, R.; Kurz-Besson, C.; Lanta, V.; Lebourgeois, F.; Miglietta, F.; Chuine, I. Variation in cold hardiness and carbohydrate concentration from dormancy induction to bud burst among provenances of three European oak species. Tree Physiol. 2007, 27, 817-825. [CrossRef]

29. O’Brien, M.J.; Leuzinger, S.; Philipson, C.D.; Tay, J.; Hector, A. Drought survival of tropical tree seedlings enhanced by nonstructural carbohydrate levels. Nat. Clim. Chang. 2014, 4, 710-714. [CrossRef]

30. Hartmann, H.; Trumbore, S. Understanding the roles of nonstructural carbohydrates in forest trees-From what we can measure to what we want to know. New Phytol. 2016, 211, 386-403. [CrossRef]

31. Plavcová, L.; Hoch, G.; Morris, H.; Ghiasi, S.; Jansen, S. The amount of parenchyma and living fibers affects storage of nonstructural carbohydrates in young stems and roots of temperate trees. Am. J. Bot. 2016, 103, 603-612. [CrossRef]

32. Pratt, R.B.; Jacobsen, A.L. Conflicting demands on angiosperm xylem: Tradeoffs among storage, transport and biomechanics Plant. Cell Environ. 2017, 40, 897-913. [CrossRef]

33. WCSP. World Checklist of Selected Plant Families. Facilitated by the Royal Botanic Gardens, Kew. Published on the Internet. Available online: http:/ /wcsp.science.kew.org/ (accessed on 2 January 2022).

34. Nixon, K.C. Infrageneric classification of Quercus (Fagaceae) and typification of sectional names. Ann. Des. Sci. For. 1993, 50, 25-34. [CrossRef]

35. Da, L.; Kang, M.; Song, K.; Shang, K.; Yang, Y.; Xia, A.; Qi, Y. Altitudinal zonation of human-disturbed vegetation on Mt. Tianmu, eastern China. Ecol. Res. 2009, 24, 1287-1299. [CrossRef]

36. Fang, J.; Wang, Z.; Tang, Z. Atlas of Woody Plants in China: Distribution and Climate; Springer: Berlin/Heidelberg, Germany, 2011.

37. Zhang, X.J.; Song, K.; Pan, Y.J.; Gao, Z.W.; Pu, F.G.; Lu, J.H.; Shang, K.K.; Da, L.J.; Cieraad, E. Responses of leaf traits to low temperature in an evergreen oak at its upper limit. Ecol. Res. 2020, 35, 900-911. [CrossRef]

38. Zhang, X. Distributional Patterns and Physiological Mechanisms of an Evergreen Broadleaved Tree Species (Cyclobalanopsis gracilis) along an Elevational Gradient in the Dabie Mountain. Ph.D. Dissertation, East China Normal Univerty, Shanghai, China, 2020

39. Song, K.; Da, L. Evergreen-deciduous broad-leaved forest ecotone in eastern China: Retrospect and new perspectives. In Vegetation Structure and Function at Multiple Spatial, Temporal and Conceptual Scales; Springer: Cham, Switzerland, 2016; pp. 129-147.

40. Song, K.; Kohyama, T.S.; Da, L. Transition patterns across an evergreen-Deciduous broad-leaved forest ecotone: The effect of topographies. J. Veg. Sci. 2014, 25, 1257-1266. [CrossRef]

41. Deng, M.; Wei, H.; Yao, G. Evergreen plants and evergreen broad-leaved forests in Huoshan and Jinzhai counties of the Dabie Mountaion region. Acta Phytoecol. Geobot. Sin. 1985, 9, 142-149.

42. Shen, $X$. The study on the vegetation of the Tiantangzhai Mountains of the Dabie Mountains, Anhui Province. J. Wuhan Bot. Res. 1989, 7, 131-139.

43. Shi, P.; Körner, C.; Hoch, G. A test of the growth-limitation theory for alpine tree line formation in evergreen and deciduous taxa of the eastern Himalayas. Funct. Ecol. 2010, 22, 213-220. [CrossRef] 
44. Buysse, J.; Merckx, R. An Improved Colorimetric Method to Quantify Sugar Content of Plant Tissue. J. Exp. Bot. 1993, 44, 1627-1629. [CrossRef]

45. Gärtner, H.; Schweingruber, F.H. Microscopic Preparation Techniques for Plant Stem Analysis; Verlag Dr. Kessel: Remagen, Germany, 2013.

46. Gärtner, H.; Banzer, L.; Schneider, L.; Schweingruber, F.H.; Bast, A. Preparing micro sections of entire (dry) conifer increment cores for wood anatomical time-series analyses. Dendrochronologia 2015, 34, 19-23. [CrossRef]

47. Kotowska, M.M.; Wright, I.J.; Westoby, M. Parenchyma abundance in wood of evergreen trees varies independently of nutrients Front. Plant Sci. 2020, 11, 86. [CrossRef]

48. Rungwattana, K.; Hietz, P. Radial variation of wood functional traits reflect size-related adaptations of tree mechanics and hydraulics. Funct. Ecol. 2018, 32, 260-272. [CrossRef]

49. Furze, M.E.; Huggett, B.A.; Chamberlain, C.J.; Wieringa, M.M.; Aubrecht, D.M.; Carbone, M.S.; Walker, J.C.; Xu, X.; Czimczik, C.I.; Richardson, A.D. Seasonal fluctuation of nonstructural carbohydrates reveals the metabolic availability of stemwood reserves in temperate trees with contrasting wood anatomy. Tree Physiol. 2020, 40, 1355-1365. [CrossRef]

50. Ohsawa, M. An interpretation of latitudinal patterns of forest limits in south and east Asian mountains. J. Ecol. 1990, 78, 326-339. [CrossRef]

51. R Core Team. R: A language and Environment for Statistical Computing; R Foundation for Statistical Computing: Vienna, Austria, 2020; Available online: https:/ / www.R-project.org/ (accessed on 2 January 2022).

52. Brooks, M.E.; Kristensen, K.; Van Benthem, K.J.; Magnusson, A.; Berg, C.W.; Nielsen, A.; Skaug, H.J.; Machler, M.; Bolker, B.M. glmmTMB balances speed and flexibility among packages for zero-inflated generalized linear mixed modeling. $R J$. 2017, 9, 378-400. [CrossRef]

53. Hartig, F. DHARMa: Residual Diagnostics for Hierarchical (Multi-Level/Mixed) Regression Models. R Package Version 0.4.4. 2021. Available online: https:/ /CRAN.R-project.org/package=DHARMa (accessed on 2 January 2022).

54. Oksanen, J.; Blanchet, F.G.; Friendly, M.; Kindt, R.; Legendre, P.; McGlinn, D.; Minchin, P.R.; O’Hara, R.B.; Simpson, G.L.; Solymos, P.; et al. vegan: Community Ecology Package. R Package Version 2.5-7. 2020. Available online: https://CRAN.R-project.org/ package=vegan (accessed on 2 January 2022).

55. Pfautsch, S.; Renard, J.; Tjoelker, M.G.; Salih, A. Phloem as Capacitor: Radial Transfer of Water into Xylem of Tree Stems Occurs via Symplastic Transport in Ray Parenchyma. Plant Physiol. 2015, 167, 963-971. [CrossRef]

56. Baas, P. The wood anatomical range in Ilex (Aquifoliaceae) and its ecological and phylogenetic significance. Blumea Biodivers. Evol. Biogeogr. Plants 1973, 21, 193-260.

57. Alves, E.S.; Angyalossy-Alfonso, V. Ecological trends in the wood anatomy of some Brazilian species. 2. Axial parenchyma, rays and fibres. IAWA J. 2002, 23, 391-418. [CrossRef]

58. Taneda, H.; Tateno, M. Hydraulic conductivity, photosynthesis and leaf water balance in six evergreen woody species from fall to winter. Tree Physiol. 2005, 25, 299-306. [CrossRef] [PubMed]

59. Gupta, P.; Gupta, S. Wood anatomy of Indian oaks, with reference to systematic, ecological and evolutionary perspectives. Nord. J. Bot. 2020, 38, 4. [CrossRef]

60. Fontes, C.G.; Pinto Ledezma, J.; Jacobsen, A.L.; Pratt, R.B.; Cavender Bares, J. Adaptive variation among oaks in wood anatomical properties is shaped by climate of origin and shows limited plasticity across environments. Funct. Ecol. 2021, 00, 1-15. [CrossRef]

61. Fisher, J.B.; Goldstein, G.; Jones, T.J.; Cordell, S. Wood vessel diameter is related to elevation and genotype in the Hawaiian tree Metrosideros polymorpha (Myrtaceae). Am. J. Bot. 2007, 94, 709-715. [CrossRef] [PubMed]

62. Yang, D.; Wang, A.; Zhang, J.; Bradshaw, C.J.A.; Hao, G. Variation in Stem Xylem Traits is Related to Differentiation of Upper Limits of Tree Species along an Elevational Gradient. Forests 2020, 11, 349. [CrossRef]

63. Morris, H.; Gillingham, M.; Plavcova, L.; Gleason, S.M.; Olson, M.E.; Coomes, D.A.; Fichtler, E.; Klepsch, M.M.; Martinez-Cabrera H.I.; McGlinn, D.J.; et al. Vessel diameter is related to amount and spatial arrangement of axial parenchyma in woody angiosperms Plant. Cell Environ. 2018, 41, 245-260. [CrossRef] [PubMed]

64. Olano, J.M.; Arzac, A.; García Cervigón, A.I.; von Arx, G.; Rozas, V. New star on the stage: Amount of ray parenchyma in tree rings shows a link to climate. New Phytol. 2013, 198, 486-495. [CrossRef]

65. Chen, Z.; Zhu, S.; Zhang, Y.; Luan, J.; Li, S.; Sun, P.; Wan, X.; Liu, S. Tradeoff between storage capacity and embolism resistance in the xylem of temperate broadleaf tree species. Tree Physiol. 2020, 40, 1029-1042. [CrossRef] [PubMed]

66. Zhu, W.; Cao, M.; Wang, S.; Xiao, W.; Li, M. Seasonal dynamics of mobile carbon supply in Quercus aquifolioides at the upper elevational limit. PLoS ONE 2012, 7, e34213. [CrossRef]

67. Furze, M.E.; Huggett, B.A.; Aubrecht, D.M.; Stolz, C.D.; Carbone, M.S.; Richardson, A.D. Whole-tree nonstructural carbohydrate storage and seasonal dynamics in five temperate species. New Phytol. 2019, 221, 1466-1477. [CrossRef]

68. Davidson, A.M.; Le, S.T.; Cooper, K.B.; Lange, E.; Zwieniecki, M.A. No time to rest: Seasonal dynamics of non-structural carbohydrates in twigs of three Mediterranean tree species suggest year-round activity. Sci. Rep. 2021, 11, 5181. [CrossRef]

69. Tixier, A.; Guzmán-Delgado, P.; Sperling, O.; Amico Roxas, A.; Laca, E.; Zwieniecki, M.A. Comparison of phenological traits, growth patterns, and seasonal dynamics of non-structural carbohydrate in Mediterranean tree crop species. Sci Rep. 2020, 10, 347. [CrossRef] 
70. Olson, M.E.; Soriano, D.; Rosell, J.A.; Anfodillo, T.; Donoghue, M.J.; Edwards, E.J.; León-Gómez, C.; Dawson, T.; Camarero Martínez, J.J.; Castorena, M.; et al. Plant height and hydraulic vulnerability to drought and cold. Proc. Natl. Acad. Sci. USA 2018, 115, 7551-7556. [CrossRef]

71. Soriano, D.; Echeverría, A.; Anfodillo, T.; Rosell, J.A.; Olson, M.E. Hydraulic traits vary as the result of tip-to-base conduit widening in vascular plants. J. Exp. Bot. 2020, 71, 4232-4242. [CrossRef] [PubMed] 